\title{
Synthesis of (Z)-Cinnamate Derivatives via Visible-Light-Driven E-to-Z Isomerization
}

\author{
Penghua Shu* \\ Haichang Xu \\ Lingxiang Zhang \\ Junping Li \\ Hao Liu \\ Yuehui Luo \\ Xue Yang \\ Zhiyu Ju \\ Zhihong Xu*
}

School of Chemistry and Chemical Engineering, Xuchang University, 88 Bayi Road, Xuchang, Henan 461000, P. R. of China

shupenghua@yeah.net

xuzhihong1980@yahoo.com

Received: 22.08.2019

Accepted after revision: 12.09.2019

Published online: 09.10.2019

DOI: 10.1055/s-0039-1690331; Art ID: so-2019-d0022-I

License terms: (c) $=\$$

(C) 2019. The Author(s). This is an open access article published by Thieme under the terms of the Creative Commons Attribution-NonDerivative-NonCommercial-License, permitting copying and reproduction so long as the original work is given appropriate credit. Contents may not be used for commercial purposes or adapted, remixed, transformed or built upon. (https://creativecommons.org/licenses/by-nc-nd/4.0/)

Abstract (Z)-Cinnamate derivatives are prevalent in natural bioactive products and in organic synthesis. Herein, we report a practical approach toward the efficient synthesis of $(Z)$-cinnamate derivatives via visible-light-driven isomerization. When $E$-isomers of cinnamate derivatives were irradiated with blue light in the presence of $1 \mathrm{~mol} \%$ $\mathrm{Ir}_{2}(\mathrm{ppy})_{4} \mathrm{Cl}_{2}$ (ppy = 2-phenylpyridine), Z-isomers were readily obtained in good yields. This strategy allows the large-scale synthesis of (Z)-cinnamate derivatives with simple purification. This convenient, mild, and green synthetic methodology was subsequently applied to the synthesis of coumarins.

Key words visible light, isomerization, $\mathrm{Ir}_{2}(\mathrm{ppy})_{4} \mathrm{Cl}_{2}$, cinnamate, coumarins

(Z)-Cinnamate derivatives are commonly encountered in natural products ${ }^{1}$ and have been widely used in organic synthesis. $^{2}$ The synthesis of $(Z)$-cinnamate derivatives has attracted interest since the early era of organic chemistry and it remains a focus of interest. Over the past ten years, many methods have been established to obtain the thermodynamically less stable $(Z)$-cinnamate derivatives, ${ }^{3}$ of which the most widely used have been semihydrogenation of alkynes with $\mathrm{Pd},{ }^{4} \mathrm{Ru},{ }^{5} \mathrm{Au},{ }^{6} \mathrm{Rh},{ }^{7} \mathrm{Cu}^{8}$ or $\mathrm{Ni}^{9}$ complexes. Wittig olefination, ${ }^{10}$ stereoselective cross-coupling, ${ }^{11}$ and olefin metathesis ${ }^{12}$ are also commonly employed methods for the efficient synthesis of $Z$-olefins. Photochemical reactions, as mild, atom-economic and environmentally benign methodologies, have been widely used in organic synthesis, ${ }^{13}$ especially in the synthesis of diazo compounds, ${ }^{14}$ heterocycles, ${ }^{15}$

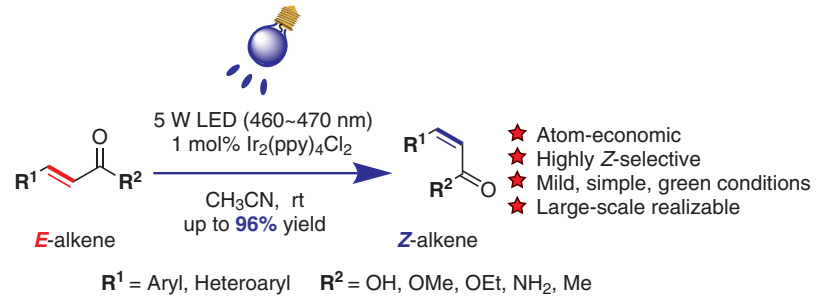

helicene-like compounds, ${ }^{16}$ natural products with complex structures, ${ }^{17}$ and thermodynamically unstable (Z)-cinnamates. $^{18}$

During our investigation of the synthetic utility of visible-light photoredox catalysts for [2+2] photodimerization, ${ }^{19}$ it was observed that the thermodynamically stable (E)-cinnamamide (1a) could be transformed into its $Z$-isomer (2a) effectively (in 65\% isolated yield), rather than forming the expected dimer, when treated with $1 \mathrm{~mol} \%$ $\mathrm{Ir}_{2}$ (ppy) ${ }_{4} \mathrm{Cl}_{2}$ (Scheme 1). Further experimentation revealed that air had no clear influence on the reaction efficiency, which made the reaction operation very convenient (Table 1 , entry 1$)$. Inspired by these interesting results, we considered developing a practical method for the synthesis of $(Z)$ cinnamate derivatives by visible-light-driven isomerization.

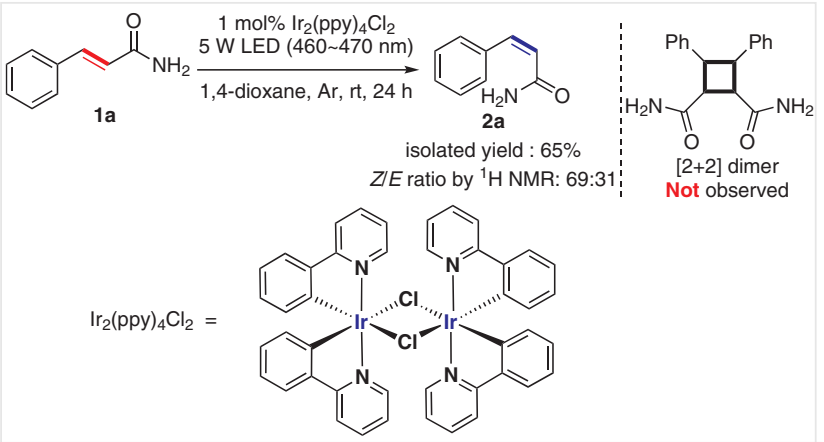

Scheme 1 Photochemical reaction of 1 a catalyzed by $\mathrm{Ir}_{2}(\mathrm{ppy})_{4} \mathrm{Cl}_{2}$

Initially, we investigated the photoisomerization of $(E)$ cinnamamide (1a) catalyzed by $1 \mathrm{~mol} \% \mathrm{Ir}_{2}(\mathrm{ppy})_{4} \mathrm{Cl}_{2}$ in different solvents. ${ }^{20}$ The results showed that the isomerization occurred smoothly in a wide range of solvents such as $\mathrm{CH}_{3} \mathrm{CN}$, DMF, DMA, DCE, and THF, which provided the application of this strategy with more options (Table 1, entries 2-6). In reactions conducted in toluene and EtOAc, only a 
Table 1 Optimization of Isomerization Conditions ${ }^{a}$

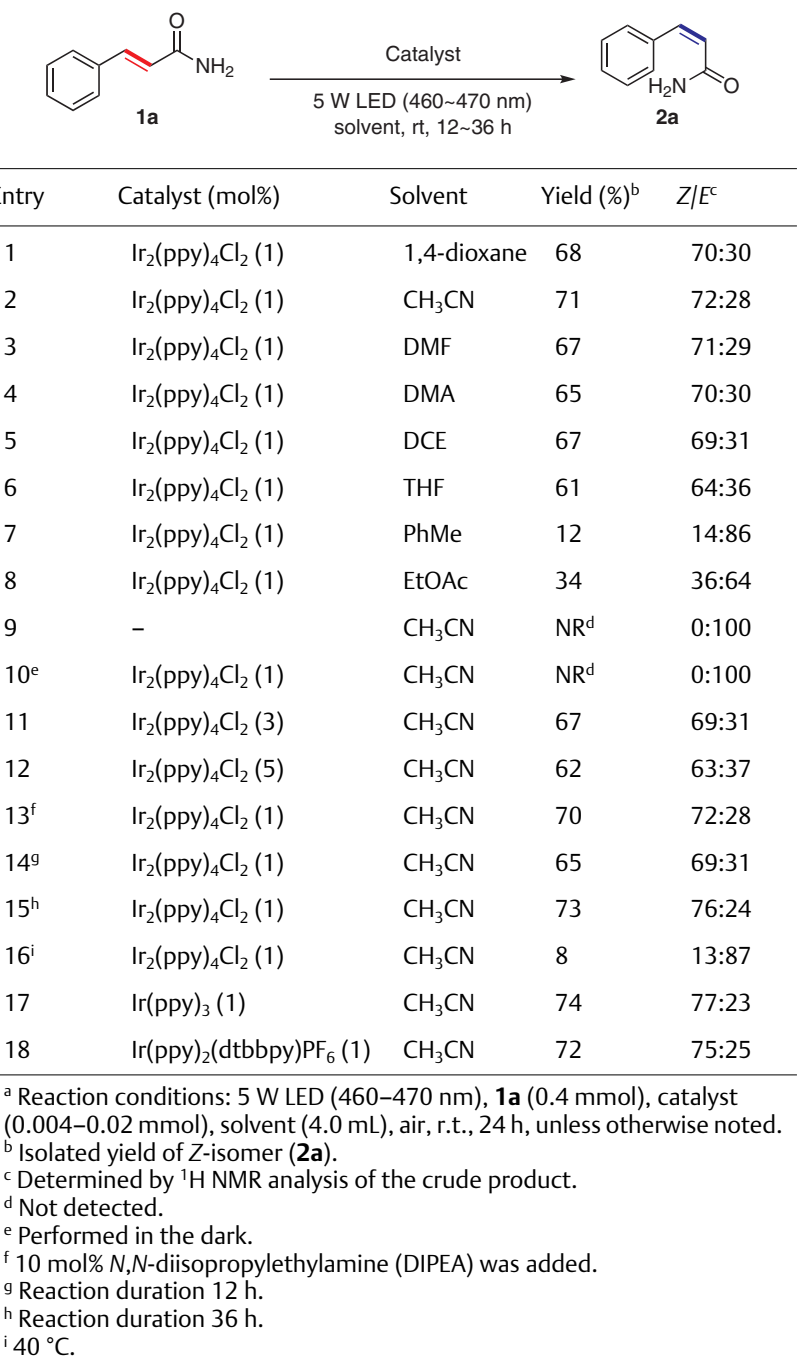

small proportion of 1a isomerized; no other by-products were observed (entries 7 and 8). Finally, $\mathrm{CH}_{3} \mathrm{CN}$ was chosen as the solvent of choice. Further experiments showed that the photocatalyst and visible light were both essential for the success of this reaction; no reaction took place in the absence of $\mathrm{Ir}_{2}(\mathrm{ppy})_{4} \mathrm{Cl}_{2}$ (entry 9) or visible light (entry 10 ). Increasing the amount of $\mathrm{Ir}_{2}(\mathrm{ppy})_{4} \mathrm{Cl}_{2}$ to 3 or $5 \mathrm{~mol} \%$ produced lower yields (entries 11 and 12). Feasibly, the higher loadings of photocatalyst increased self-quenching and reduced light penetration into the reaction solution. The influence of external base on this isomerization was also studied, with addition of $10 \mathrm{~mol} \% \mathrm{~N}, \mathrm{~N}$-diisopropylethylamine (DIPEA) (entry 13). However, no clear influence on the reaction efficiency was observed. To demonstrate the equilibrium point in this $E$-to- $Z$ isomerization, the reaction times were set as $12 \mathrm{~h}$ and $36 \mathrm{~h}$, respectively (entries 14 and 15 , vs. entry 1 ). This indicated that $24 \mathrm{~h}$ was required to obtaining efficient conversion. To test the effect of temperature on the yield of $Z$-isomer, the reaction temperature was set at $40{ }^{\circ} \mathrm{C}$ (entry 16 vs. entry 1 ). However, only $8 \%$ of 2a was obtained after $24 \mathrm{~h}$. This might be due to the fact that $\mathrm{Ir}_{2}(\mathrm{ppy})_{4} \mathrm{Cl}_{2}$ is temperature sensitive and loses its catalytic capability at the higher temperature. When compared to other commercial available photoredox catalysts, such as $\operatorname{Ir}(\text { ppy })_{3}{ }^{18 \mathrm{~b}}$ (entry 17) and $\operatorname{Ir}(\text { ppy })_{2}(\mathrm{dtbbpy}) \mathrm{PF}_{6}{ }^{17 \mathrm{~d}}$ (entry 18), which have been reported to be effective catalysts for obtaining $Z$-alkenes, $\mathrm{Ir}_{2}$ (ppy) ${ }_{4} \mathrm{Cl}_{2}$ afforded a similar yield. However, it should be noted that, among the three studied photoredox catalysts, $\mathrm{Ir}_{2}(\mathrm{ppy})_{4} \mathrm{Cl}_{2}$ was the most economical.

An optimization of light sources with different wavelengths $(\lambda)$ and powers (W) was also carried out (Table 2 ). This study showed that $5 \mathrm{~W}$ blue light with wavelengths between 460 and $470 \mathrm{~nm}$ afforded the best selectivity (entry 4 ). When the reaction was simply exposed to sunlight, little conversion to the $Z$-isomer was observed. Based on these results, we finally established optimal reaction conditions for the $E$-to- $Z$ isomerization to be $1 \mathrm{~mol} \% \mathrm{Ir}_{2}(\mathrm{ppy})_{4} \mathrm{Cl}_{2}$ in $\mathrm{CH}_{3} \mathrm{CN}$, irradiated with a $5 \mathrm{~W}$ blue LED lamp $(\lambda \approx 460-470$ $\mathrm{nm}$ ) for $24 \mathrm{~h}$ at room temperature. The reaction apparatus was set up as shown in Figure 1.

Table 2 Optimization of Light Source

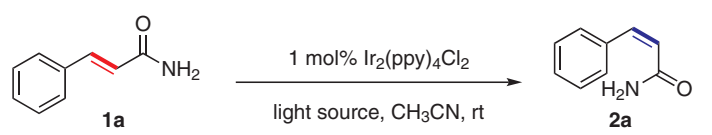

\begin{tabular}{|c|c|c|c|c|}
\hline Entry & Light source & $\lambda(\mathrm{nm})$ & Yield (\%) & $Z \mid E^{\mathrm{c}}$ \\
\hline 1 & 5 W LED & $400-415$ & 42 & $43: 57$ \\
\hline 2 & 5 W LED & $420-430$ & 48 & $50: 50$ \\
\hline 3 & 5 W LED & $440-445$ & 69 & $72: 28$ \\
\hline 4 & 5 W LED & $460-470$ & 71 & $73: 27$ \\
\hline 5 & 5 W LED & $480-485$ & 27 & $28: 72$ \\
\hline 6 & 5 W LED & $490-495$ & 11 & $13: 87$ \\
\hline 7 & 7 W LED & $460-470$ & 70 & $72: 28$ \\
\hline 8 & 10 W LED & $460-470$ & 71 & $73: 27$ \\
\hline 9 & sunlight & - & trace & 2:98 \\
\hline \multicolumn{5}{|c|}{ 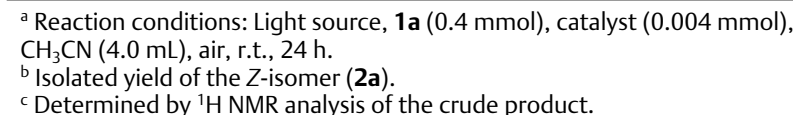 } \\
\hline
\end{tabular}

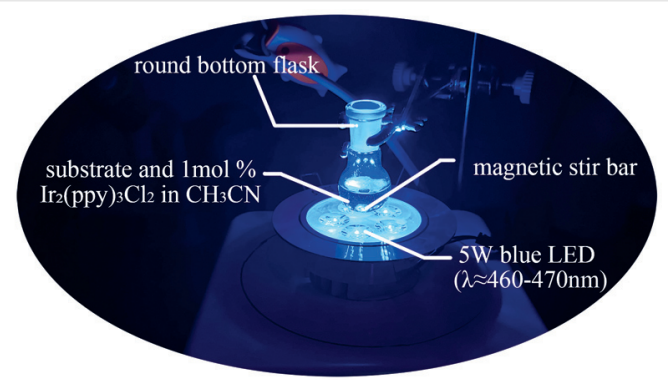

Figure 1 Reaction apparatus for photochemical isomerization 
With these optimized reaction conditions in hand, we next investigated the scope of $(E)$-cinnamate derivatives that could be applicable to the transformation (Table 3 ).

Table 3 Scope of Photocatalytic Isomerization ${ }^{a}$

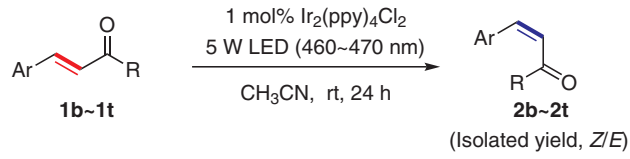

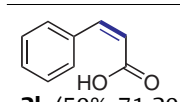

2b (59\%, 71:29)

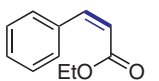

2e $(57 \%, 64: 36)$

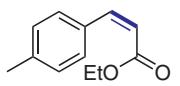

$2 \mathrm{~h}(62 \%, 64: 36)$

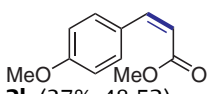

2k $(37 \%, 48: 52)$
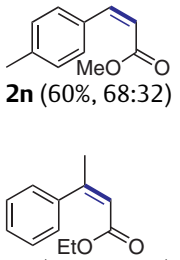

$2 q(70 \%, 75: 25)$

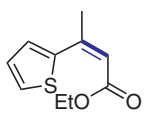

$2 t(60 \%, 67: 33)$

a Reaction conditions: 5 W LED (460 470 nm), 1b-t (0.4 mmol), catalyst $(0.004 \mathrm{mmol}), \mathrm{CH}_{3} \mathrm{CN}(4.0 \mathrm{~mL})$, air, r.t., $24 \mathrm{~h}$; isolated yield of the $Z$-isomer; $\mathrm{Z} \mid \mathrm{E}$ ratio was determined by ${ }^{1} \mathrm{H}$ NMR analysis of the crude product.

b The reaction was conducted on a 2-gram scale.

Various $(E)$-cinnamate derivatives with electron-withdrawing, electron-donating and neutral substituents at the ortho-, meta-, or para-positions of the benzene ring underwent $E$-to- $Z$ isomerization smoothly, giving the corresponding $Z$-isomers $\mathbf{2 b - t}$ in modest to high yields. From the results shown in Table 3, it can be concluded that electronwithdrawing substituents promoted this transformation, with yields of $Z$-isomers increasing notably when $\mathrm{F}, \mathrm{CF}_{3}$, or $\mathrm{Cl}$ groups are present $(\mathbf{2} \mathbf{i}, \mathbf{2} \mathbf{j}, \mathbf{2} \mathbf{p})$. However, a range of substituents were well tolerated, and no other products could be detected other than the two isomeric alkenes. In some cases, the efficiency of this isomerization could be enhanced by introducing a methyl substituent onto the $\beta$-position of the double bond (eg. $\mathbf{2 q}$ vs. 2e), which is consistent with previous reports. ${ }^{18 \mathrm{~b}}$ The isomerization of substituted heterocycles also occurred smoothly to give the $Z$-isomers $(\mathbf{2 s}, \mathbf{2 t})$. To test whether the reaction could proceed efficiently at a larger scale, we carried out the isomerization of (E)-methyl-4-hydroxycinnamate (11) on a 2-gram scale, which gave $\mathbf{2 1}$ in $53 \%$ yield. The $E$-isomer (11) could be readily removed by repeated crystallization from methanol.

A plausible pathway for the $E$-to- $Z$ transformation is proposed based on the experimental data and literature. ${ }^{18 \mathrm{~b}, 21}$ The addition of DIPEA, which is a common strategy to promote photoredox reaction, ${ }^{22}$ did not facilitate this $E$-to- $Z$ transformation (Table 1 , entry 13). Therefore, we propose that an energy-transfer (ET) process occurs in this isomerization, rather than an outer-sphere single-electrontransfer (SET) process (Scheme 2). After absorbing a photon, the photocatalyst in its singlet ground state $\operatorname{PC}\left(\mathrm{S}_{0}\right)$ is excited to the first singlet excited state ${ }^{*} \mathrm{PC}\left(\mathrm{S}_{1}\right)$, which relaxes to the triplet excited state ${ }^{*} \mathrm{PC}(\mathrm{T} 1)$ through internal conversion and successive fast intersystem crossing (ISC). The energy transfer between ${ }^{*} \mathrm{PC}\left(\mathrm{T}_{1}\right)$ and ${ }^{*} \mathrm{Q}\left(\mathrm{S}_{0}\right)$ regenerates the $\mathrm{PC}\left(\mathrm{S}_{0}\right)$ and provides ${ }^{*} \mathrm{Q}\left(\mathrm{T}_{1}\right)$ to engage in the photochemical isomerization reaction. The selectivity of the $E$-to- $Z$ isomerization is determined by the different rates of the photo-quenching of the ${ }^{*} \mathrm{PC}\left(\mathrm{T}_{1}\right)$ by the two isomers. Generally, the $E$-isomer quenches the ${ }^{*} \mathrm{PC}\left(\mathrm{T}_{1}\right)$ at a faster speed than its $Z$-isomer, thus resulting in an increase in the amount of $Z$-isomer in this process. ${ }^{17 \mathrm{c}, 21 \mathrm{~b}}$

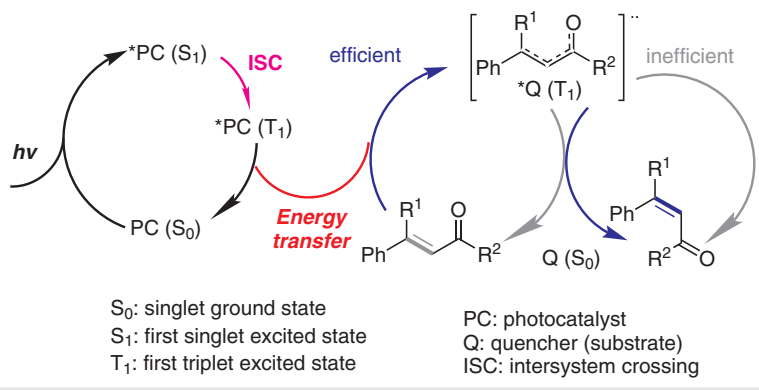

Scheme 2 Plausible pathway for the $E$-to- $Z$ isomerization

Encouraged by the range of successful isomerization examples, we speculated that this facile and practical $E$-to- $Z$ isomerization of cinnamate derivatives under mild conditions could be used as an attractive synthetic methodology in organic synthesis. Coumarins, a class of oxygen-containing heterocycles bearing a typical benzopyrone framework, are widely distributed in plants and they exhibit broad biological activities. ${ }^{23}$ Among the various methods developed for the synthesis of coumarin derivatives, ${ }^{24}$ we considered that cyclization of ortho-hydroxycinnamates via doublebond isomerization might prove to be convenient and atom-economic. Thus, we tested our optimized reaction conditions for the synthesis of coumarins and were delighted to obtain the target compounds efficiently (Table 4). ${ }^{25}$ 
Table 4 Synthesis of Coumarins via Photochemical Isomerizationª

$$
\underset{\mathrm{CH}_{3} \mathrm{CN}, \mathrm{rt}, 72 \mathrm{~h}}{5 \mathrm{~W} \mathrm{LED}(460 \sim 470 \mathrm{~nm})}
$$

\begin{tabular}{|c|c|c|}
\hline Entry Substrate & Product & $\begin{array}{l}\text { Isolated yield } \\
\text { (\%) }\end{array}$ \\
\hline
\end{tabular}

$$
\text { (2) }
$$

In summary, we have developed a practical and efficient strategy for the synthesis of $(Z)$-cinnamate derivatives by visible-light-driven isomerization with $\mathrm{Ir}_{2}(\mathrm{ppy})_{4} \mathrm{Cl}_{2}$ as the photocatalyst. Z-Isomers of cinnamate derivatives could be readily obtained in good to excellent yields. These mild, convenient reaction conditions could be used as an effective methodology for the synthesis of coumarins.

\section{Funding Information}

This work was financially supported by the National Natural Science Foundation of China (No. 21702178), the Key Scientific Research Project of Colleges and Universities in Henan Province (No. 18A350010), the Science and Technology Department of Henan Province (No. 182102311108), and the Excellent Young Key Teacher Funding Project of Xuchang University (No. 2017).

\section{Supporting Information}

Supporting information for this article is available online at https://doi.org/10.1055/s-0039-1690331.

\section{References and Notes}

(1) (a) Ibrahim, A. M.; Mansoor, A. A.; Gross, A.; Ashfaq, M. K.; Jacob, M.; Khan, S. I.; Hamann, M. T. J. Nat. Prod. 2009, 72, 2141. (b) Li, T.; Kongstad, K. T.; Staerk, D. J. Nat. Prod. 2019, 82, 249. (c) Shuab, R.; Lone, R.; Koul, K. K. Acta Physiol. Plant. 2016, 38, 64.
(2) (a) Fukuda, H.; Nishikawa, K.; Fukunaga, Y.; Okuda, K.; Kodama, K.; Matsumoto, K.; Kano, A.; Shindo, M. Tetrahedron 2016, 72, 6492. (b) Shing, T. K. M.; Luk, T.; Lee, C. M. Tetrahedron 2006, 62, 6621.

(3) Siau, W. Y.; Zhang, Y.; Zhao, Y. Top. Curr. Chem. 2012, 327, 33.

(4) For representative reports, see: (a) Kuwahara, Y.; Kango, H.; Yamashita, H. ACS Catal. 2019, 9, 1993. (b) Iwasaki, R.; Tanaka, E.; Ichihashi, T.; Idemoto, Y.; Endo, K. J. Org. Chem. 2018, 83, 13574. (c) Prabusankar, G.; Sathyanarayana, A.; Raju, G.; Nagababu, C. Asian J. Org. Chem. 2017, 6, 1451. (d) Surmiak, S. K.; Doerenkamp, C.; Selter, P.; Peterlechner, M.; Schaefer, A. H.; Eckert, H.; Studer, A. Chem. Eur. J. 2017, 23, 6019. (e) Maesing, F.; Nuesse, H.; Klingauf, J.; Studer, A. Org. Lett. 2017, 19, 2658. (f) Maesing, F.; Wang, X.; Nuesse, H.; Klingauf, J.; Studer, A. Chem. Eur. J. 2017, 23, 6014. (g) Du, W.; Gu, Q.; Li, Y.; Lin, Z.; Yang, D. Org. lett. 2017, 19, 316. (h) Jagtap, S. A.; Sasaki, T.; Bhanage, B. M. J. Mol. Catal. A: Chem. 2016, 414, 78. (i) Slack, E. D.; Gabriel, C. M.; Lipshutz, B. H. Angew. Chem. Int. Ed. 2014, 53, 14051.

(5) Jagtap, S. A.; Bhanage, B. M. Mol. Catal. 2018, 460, 1.

(6) For representative reports, see: (a) Wissing, M.; Niehues, M.; Ravoo, B. J.; Studer, A. Eur. J. Org. Chem. 2018, 3403. (b) Li, S.-S.; Tao, L.; Wang, F.-Z.-R.; Liu, Y.-M.; Cao, Y. Adv. Synth. Catal. 2016, 358, 1410. (c) Liang, S.; Hammond, G. B.; Xu, B. Chem. Commun. 2016, 52, 6013. (d) Mitsudome, T.; Yamamoto, M.; Maeno, Z.; Mizugaki, T.; Jitsukawa, K.; Kaneda, K. J. Am. Chem. Soc. 2015, 137, 13452. (e) Vasilikogiannaki, E.; Titilas, I.; Vassilikogiannakis, G.; Stratakis, M. Chem. Commun. 2015, 51, 2384.

(7) (a) Jagtap, S. A.; Bhanage, B. M. ChemistrySelect 2018, 3, 713. (b) Kiryutin, A. S.; Yurkovskaya, A. V.; Lukzen, N. N.; Vieth, H.M.; Ivanov, K. L. J. Chem. Phys. 2015, 143, 234203-1.

(8) Fedorov, A.; Liu, H.-J.; Lo, H.-K.; Coperet, C. J. Am. Chem. Soc. 2016, 138, 16502 .

(9) Richmond, E.; Moran, J. J. Org. Chem. 2015, 80, 6922.

(10) For representative reports, see: (a) Kumar, P.; Dey, R.; Banerjee, P. Org. Lett. 2018, 20, 5163. (b) Dey, R.; Kumar, P.; Banerjee, P. J. Org. Chem. 2018, 83, 5438. (c) Weissenborn, M. J.; Loew, S. A.; Borlinghaus, N.; Kuhn, M.; Kummer, S.; Rami, F.; Plietker, B.; Hauer, B. ChemCatChem 2016, 8, 1636. (d) Abascal, N. C.; Lichtor, P. A.; Giuliano, M. W.; Miller, S. J. Chem. Sci. 2014, 5, 4504. (e) Zhang, B.; Lv, C.; Li, W.; Cui, Z.; Chen, D.; Cao, F.; Miao, F.; Zhou, L. Chem. Pharm. Bull. 2015, 63, 255.

(11) (a) Cheung, C. W.; Zhurkin, F. E.; Hu, X. J. Am. Chem. Soc. 2015, 137, 4932. (b) Lee, H.; Mane, M. V.; Ryu, H.; Sahu, D.; Baik, M. H.; Yi, C. S. J. Am. Chem. Soc. 2018, 140, 10289.

(12) (a) Ahmed, T. S.; Grubbs, R. H. Angew. Chem. Int. Ed. 2017, 56 , 11213. (b) Montgomery, T. P.; Johns, A. M.; Grubbs, R. H. Catalysts 2017, 7, 87. (c) Herbert, M. B.; Grubbs, R. H. Angew. Chem. Int. Ed. 2015, 54, 5018. (d) Mann, T. J.; Speed, A. W.; Schrock, R. R.; Hoveyda, A. H. Angew. Chem. Int. Ed. 2013, 52, 8395.

(13) Hoffmann, N. Chem. Rev. 2008, 108, 1052.

(14) Ciszewski, L. W.; Rybicka-Jasinska, K.; Gryko, D. Org. Biomol. Chem. 2019, 17, 432.

(15) For reviews, see: (a) Kaur, N. J. Heterocycl. Chem. 2019, 56, 1141. (b) Kaur, N. Synth. Commun. 2018, 48, 1259. (c) Kaur, N. Curr. Org. Synth. 2018, 15, 298. (d) Kaur, N. Curr. Org. Synth. 2017, 14, 972.

(16) Hoffmann, N. J. Photochem. Photobiol., C 2014, 19, 1. 
(17) (a) Bach, T.; Hehn, J. P. Angew. Chem. Int. Ed. 2011, 50, 1000. (b) Ando, Y. Yuki Gosei Kagaku Kyokaishi 2010, 68, 1067. (c) Weaver, J. D.; Singh, K.; Staig, S. J. Am. Chem. Soc. 2014, 136, 5275. (d) Fabry, D. C.; Ronge, M. A.; Rueping, M. Chem. Eur. J. 2015, 21, 5350.

(18) (a) Bhadra, M.; Kandambeth, S.; Sahoo, M. K.; Addicoat, M.; Balaraman, E.; Banerjee, R. J. Am. Chem. Soc. 2019, 141, 6152. (b) Zhan, K.; Li, Y. Catalysts 2017, 7, 337. (c) Metternich, J. B.; Gilmour, R. Synlett 2016, 27, 2541.

(19) (a) Lei, T.; Zhou, C.; Huang, M.-Y.; Zhao, L.-M.; Yang, B.; Ye, C.; Xiao, H.; Meng, Q.-Y.; Ramamurthy, V.; Tung, C.-H.; Wu, L.-Z. Angew. Chem. Int. Ed. 2017, 56, 15407. (b) Pagire, S. K.; Hossain, A.; Traub, L.; Kerres, S.; Reiser, O. Chem. Commun. 2017, 53, 12072.

(20) Typical Synthetic Procedure: A solution of 1a $(0.4 \mathrm{mmol})$ and $\mathrm{Ir}_{2}$ (ppy) ${ }_{4} \mathrm{Cl}_{2}(1 \mathrm{~mol} \%)$ in $\mathrm{CH}_{3} \mathrm{CN}(4.0 \mathrm{~mL})$ was irradiated at room temperature with $5 \mathrm{~W}$ blue LED for $24 \mathrm{~h}$. The solvent was then removed under reduced pressure and the residue was purified by flash chromatography on silica gel to afford $\mathbf{2 a}(71 \%)$ as a white solid; mp $85-86.5{ }^{\circ} \mathrm{C} ; R_{f}=0.50$ (petroleum/EtOAc, $1: 2$ ). ${ }^{1} \mathrm{H}$ $\operatorname{NMR}\left(400 \mathrm{MHz}, \mathrm{CD}_{3} \mathrm{OD}\right): \delta=7.53(\mathrm{~d}, J=7.2 \mathrm{~Hz}, 2 \mathrm{H}), 7.34-7.26$ $(\mathrm{m}, 3 \mathrm{H}), 6.75(\mathrm{~d}, J=12.8 \mathrm{~Hz}, 1 \mathrm{H}), 6.02(\mathrm{~d}, J=12.8 \mathrm{~Hz}, 1 \mathrm{H}) .{ }^{13} \mathrm{C}$ NMR $\left(100 \mathrm{MHz}, \mathrm{CD}_{3} \mathrm{OD}\right): \delta=172.7,138.3,136.8,130.4,129.7$, 129.4, 124.3.
(21) (a) Schultz, D. M.; Yoon, T. P. Science 2014, 343, 1239176. (b) Metternich, J. B.; Gilmour, R. J. Am. Chem. Soc. 2015, 137, 11254.

(22) Shaw, M. H.; Twilton, J.; MacMillan, D. W. C. J. Org. Chem. 2016, $81,6898$.

(23) (a) Srikrishna, D.; Dubey, P. K.; Godugu, C. Mini-Rev. Med. Chem. 2018, 18, 113. (b) Pereira, T. M.; Franco, D. P.; Vitorio, F.; Kummerle, A. E. Curr. Trends Med. Chem. 2018, 18, 124.

(24) For representative reports, see: (a) Metternich, J. B.; Gilmour, R. J. Am. Chem. Soc. 2016, 138, 1040. (b) Salem, M. A.; Helal, M. H.; Gouda, M. A.; Ammar, Y. A.; El-Gaby, M. S. A.; Abbas, S. Y. Synth. Commun. 2018, 48, 1534. (c) Moskvina, V. S.; Khilya, V. P. Chem. Heterocycl. Compd. 2019, 55, 300.

(25) Typical Synthetic Procedure: A solution of $1 \mathbf{u}(0.4 \mathrm{mmol})$ and $\mathrm{Ir}_{2}$ (ppy) ${ }_{4} \mathrm{Cl}_{2}(1 \mathrm{~mol} \%)$ in $\mathrm{CH}_{3} \mathrm{CN}(4 \mathrm{~mL})$ was irradiated at room temperature with a $5 \mathrm{~W}$ blue LED light for $72 \mathrm{~h}$. The solvent was then removed under reduced pressure and the residue was purified by flash chromatography on silica gel to afford $2 \mathbf{u}(94 \%)$ as a white solid; mp $70-71.4{ }^{\circ} \mathrm{C} ; R_{f}=0.35$ (petroleum-EtOAc, 3:1). ${ }^{1} \mathrm{H}$ NMR $\left(400 \mathrm{MHz}, \mathrm{CDCl}_{3}\right): \delta=7.65(\mathrm{~d}, J=9.6 \mathrm{~Hz}, 1 \mathrm{H}), 7.48$ $(\mathrm{m}, 1 \mathrm{H}), 7.42(\mathrm{~d}, J=7.6 \mathrm{~Hz}, 1 \mathrm{H}), 7.27(\mathrm{~d}, J=8.4 \mathrm{~Hz}, 1 \mathrm{H}), 7.21(\mathrm{~d}$, $J=7.2 \mathrm{~Hz}, 1 \mathrm{H}), 6.39(\mathrm{~d}, J=9.6 \mathrm{~Hz}, 1 \mathrm{H}) .{ }^{13} \mathrm{C}$ NMR $(100 \mathrm{MHz}$, $\left.\mathrm{CDCl}_{3}\right): \delta=161.0,154.3,143.6,132.0,128.1,124.6,119.0,117.1$, 116.9. 